\title{
Role of Media in Portraying Ebola in and outside Africa
}

\section{Ibrahim Yusuf ${ }^{*}$, Sani Yahaya ${ }^{1}$ and Saleh Qabli ${ }^{2}$}

${ }^{1}$ Department of Microbiology, Faculty of Science, Bayero University, P.M.B 3011, Kano, Nigeria

${ }^{2}$ Department of Biology, King Abdulaziz University, Jeddah, Saudi Arabia

The horrific Ebola virus disease (EVD) outbreaks in West Africa and some parts of the world, has dominated most of the headlines in print, visual and social media recently. The nature of coverage and broadcast of the whole epidemic by media, has thrown unnecessary fear to many, due to its unique mode of killing, spread and its current status of no vaccine or drugs.

The recent Editorial in The Lancet, where the editorial pointed out that coverage of Ebola by media are prolific but sometimes narrow and unbalanced, reached us at the right time, when the issue is being debated [1]. We have been following responses and comments of Africans and non-Africans to different media information regarding EVD in West Africa since its outbreak in March 2014 till date. We have summarised and have the following to comment.

Even though, the prolific and the unbalanced media coverage of EVD in the West African sub-continent by some media has fuelled the growing panic in many part of the globe; the nature of coverage by local media provides handful of benefits for some countries in the region in fighting the disease. For instance, the wide coverage by local TV and radio stations and social media has at least raised the level of awareness of common people with no access to internet, electricity or satellite in the region, on the dangers of the disease and at least some preventive measure in the midst of the growing panic over Ebola. While the government and private own media broadcasts live and rerun programmes by professional medical and public health experts on the true causes, symptoms, mode of spread and prevention and control measures, the social media also supported the spread of the message by exaggerating and giving non-professional and even dangerous solutions. However, the duo has successfully contributed to successes recorded in less or non-hit countries in the region such as Nigeria, Senegal, Ghana and Mali, due to scaring number of death and collapse of socio-economy and food in-security in the worst affected countries.

The disproportionate coverage and special important attached to few confirmed cases of EVD in the United States and Spain by the western media, has also help reversed the belief of those that hold the view that Ebola does not really exist and those saying EVD is western effort to reduce African population, to certain level. It has also raised the hope of many, that the initial reluctant global support, will at least double or triple since the virus has find it way outside Africa, because they believed that a single victim in the United States or Europe, will attract prompt international intervention and wide media coverage which hundreds of dying Africans did not receive.

The intensified Ebola fear on social media such as twitter, facebook etc. due the gross spreads of misinformation from non-professionals and unfortunate reports in the region by print media of suspicions, protesting, rioting and attacks [2] against health care workers who are in frontline in fighting the disease, has resulted not only to fanning the flames of Ebola hysteria and untimely deaths, but also led to more harsh treatments to Africans in diaspora and those on transit. The exponential rising figures of casualties and coverage of the whole scenario in the most hit countries and their neighbours, has subjected Africans to unnecessary hardships such as fear for sitting beside them in airplane, bus, train after passing thorough checks at the entry, sack from working after visiting Ebola free country in Africa [3], hatred and abuse in international football tournament, refusing Africans entry into some countries and at least subjecting them to tough screening.

The mode of reports of the few media houses, covering the epidemic in the region, focussing more on horrific situations associated with the epidemic, while remain almost silent on the efforts put in place by the local authorities, has strengthen the belief by many in the region that most western media only paid attention to reports of terrible situations when it comes to Africa, and thereby neglects the reports. Hundreds of African tweets and comments, capitalised on the report of US refusal to honour Nigeria's request for ZMapp drug- the drug used by the US to treat the first 2 infected American volunteers in Africa, to justify their claims. This view almost matched with the view of other eminent Africans such as Kofi Anan, former UN secretary, who says "when you look at the evolution of the crisis, the international community really woke up when the disease got to America and Europe" during an interview with BBC [4]. By September, 2014, most of those that commented on refusal to use experimental drugs by CDC, bitterly commented again when an American Ebola survivor was quoted saying "the CDC has declared me safe and free of the virus" and that the "care was so excellent, so speedy, so prompt."

We believed that media have a significant role to play in addressing issues like this. We are of the view of the majority and editorial that the absolute key is getting the host community on board, relieving the respected volunteered western health workers of stigma and isolation they faced when returned home. The coverage by the western media and social media would have yield positive results if focused on prevention measures before outbreaks of any disease in any of high risk areas, or role of some cultural believes in fuelling disease outbreak and spread, in collaboration with local communities targeting rural areas most, where the outbreaks always begin. It is then that "local solutions to local problems need Africans training Africans. DRC supporting Guinea. Good regional solidarity-a wealth of experience within Africa" as quoted by the editorial, will hold. The awareness campaign on importance of immunization against measles, poliomyelitis, roll back malaria, protection against sexually transmitted diseases such as HIV/AIDs on local print media, televisions, radio and even internet which focused the public have yielded positive results in the past in the region. But the western media constant coverage and reports of disasters, civil war, diseases, poverty and food shortages in the region, has contributed to initial rejection of the true existence of the disease in

*Corresponding author: Ibrahim Yusuf, Department of Microbiology and Medical Laboratory Science, Bayero University, Kano, P.M.B. 3011, Kano Nigeria, Tel: +2347037865734; E-mail: iyusuf.bio@buk.edu.ng

Received January 01, 2015; Accepted January 01, 2015; Published February 10, 2015

Citation: Yusuf I, Yahaya S, Qabli S (2015) Role of Media in Portraying Ebola in and outside Africa. J Trop Dis 3: 152. doi: 10.4172/2329-891X.1000152

Copyright: (c) 2015 Yusuf I. This is an open-access article distributed under the terms of the Creative Commons Attribution License, which permits unrestricted use, distribution, and reproduction in any medium, provided the original author and source are credited. 
the affected communities (understood from comments over 3 months since the outbreak).

The biased and unbalanced coverage of the epidemic by many United States media houses, contributed immensely in unnecessary aggravating the emotional climate of fear in the US. While, the epidemic that have rampaged the region for about four months since its declaration, with about 1,400 people infected and over 50\% death as at August, did not receive even the slightest attention from many US media, but now tops the headlines after the virus landed on its soil in September 2014. The sudden change of headlines from "No Cure for Ebola", "no vaccination against it", "one of the world's most deadly diseases" when the virus was only in Africa, to "Experimental drug likely saved Ebola patients" [5] after it crossed many tight borders to America, clearly indicates biased and unbalanced coverage.

Though we applaud the livestream, photo, print and social media coverage of this global outbreak, for at least providing a relatively level picture of disease's spread, prevention measures and need for global interaction and sharing of information. Nonetheless, the coverage have not only increase fear and anxiety among people, but have failed to provide enough awareness on how to prevent the outbreak in the first place and appeared to be unbalanced in the coverage of the whole situation, not in favour of Africans.

\section{References}

1. The Lancet (2014) The medium and the message of Ebola. The Lancet 384 9955.

2. Al Jazeera News, http://www.aljazeera.com/news/africa/2014/09/deadly-attackguinea-ebola-team-2014918211547560228.html. (Assessed 14 September 2014)

3. Metro, 2014. http://metro.co.uk/2014/11/05/security-guard-banned-from-workover-ebola-fears-after-he-went-to-nigeria-4935683/. (Assessed 10 November 2014)

4. BBC News Africa. http://www.bbc.com/news/world-africa-29648598. (Assessed 14 November 2014)

5. CNN. http://edition.cnn.com/2014/08/04/health/experimental-ebola-serum/ index.html. (Assessed 14 November 2014). 